\title{
Energy Efficient Design and Energy Sharing Potential of Urban-Community
}

\author{
Ali Muslim Syed ${ }^{1}$, Caroline H-Vermette ${ }^{2}$ \\ ${ }^{1}$ Research Associate, Faculty of Environmental Design, University of Calgary, Calgary, Canada \\ ${ }^{2}$ Assistant Professor, Faculty of Environmental Design, University of Calgary, Calgary, Canada
}

\begin{abstract}
This paper presents the results of a simulation study of an urban centric retail-residential complex and explores energy efficient building design parameters and energy sharing strategies within both building types of the complex. The results show that with an integrated building design approach, cutting edge technologies and high energy efficiency measures a net reduction of $29 \%$ energy in the retail, $32 \%$ for row house and $41 \%$ for the detached house model is achieved compared to design complying with the minimum requirement of the applicable energy code. By adding building integrated solar photovoltaic (BIPV) system, a net reduction of 86 $\%$ in electrical energy import to the retail, $100 \%$ for row house and $96 \%$ for the detached house model is achieved. Additionally by sharing waste heat recovered from retail refrigeration compressor racks, up to $68 \%$ of the space and ventilation heating demand of the retailresidential complex can be met. It has been found that by feasible combination of buildings designed to harness on-site energy and sharing energy between the individual buildings, dependence on utility grids can be reduced for climate change resilient urban infrastructure.
\end{abstract}

\section{Introduction}

World's cities consume 76\% of global energy (Seto et al. 2014) and contribute to $70 \%$ of global greenhouse gas (GHG) emissions while occupying only $2 \%$ of the world's land surface (UN-Habitat, 2014). Commercial and residential buildings contribute to $28 \%$ and $29 \%$ of the Global GHG emissions in urban built environment respectively (UN-Habitat, 2011; 2014). In Canada the residential sector makes up $13 \%$ of total end-use demand in 2017, while the commercial sector consumes $12 \%$ (National Energy Board, 2018).

Future projections of population densification together with climate change risks create new opportunities for an expanded role of sustainability in urban communities.

Several research studies and energy standards have explored the best design practices and energy conservation measures (ECM) that enable reduction in the energy consumption in the residential and retail sectors by $40 \%$ or higher (AEDG, 2011; ASHRAE 90.1, 2016; ASHRAE 189.1, 2014; Doty, 2008; Syed \& Hachem, 2019). However, even such energy saving benchmarks are not sufficient to address the projected energy demand of the urban built infrastructure
(Hachem-Vermette et al. 2018). Hence, there is a need to couple ECMs and onsite renewable energy generation to reduce dependance on utility grids.

In addition, studies have explored the viability of energy sharing between individual buildings in a cluster of buildings to further reduce the energy wastage and reduce energy footprint of an urban community. Kayo and Ooka (2010a) have explored building energy system optimization by utilizing waste heat from cogeneration by means of genetic algorithm. Chung et al. (2012) explores energy sharing system optimization of a combined heat and power (CHP) plant applied to a mixture of buildings comprising residential, offices, hospitals, retail and schools. Chung et al. (2012) shows that with optimal selection of building types and proper system size selection, energy sharing between buildings is a viable option when using CHP system. Kayo et al. (2014) concludes that for an energy community comprising of an office building, hotel, hospital and a retail centre, a CHP plant with energy sharing within the energy cluster can offer better energy management within the boundary compared to treating buildings as separate cases. In another study, Kayo and Ooka (2010b) have explored energy sharing between an office and apartment building and shown significant reduction in energy consumption of the cluster by using waste heat from the office building. Syed and Hachem (2019) have explored an urban centric greenhouse-retail complex for energy efficient design parameters, integrating renewable energy technologies and exploring energy sharing strategies within the complex. Syed and Hachem (2019) show that with an integrated building design approach, cutting edge technologies and high energy efficiency measures a net reduction of $27 \%$ energy in the greenhouse-retail complex is achieved compared to design complying with the minimum requirement of the applicable energy codes. Additionally, by sharing waste heat recovered from retail refrigeration compressor racks, $21 \%$ of space and ventilation heating demand of the greenhouse and energy demand for irrigation water and service hot water for the complex can be met.

The current study aims at exploring a progressively energy efficient urban-centric residential sector, coupled with retail amenity. The retail-housing complex design has been improved using innovative research in energy systems and on-site renewable energy generation. This study also explores the potential of energy sharing 
between the individual buildings of the complex to reduce dependence on utility grid.

Additionally, life cycle cost and environmental impact can be used as supporting tools in the design of buildings. Although this aspect is not studied in the current paper, introducing such study can provide a more holistic understanding of the environmental impact of various technologies and design strategies implemented.

\section{Methodology of the Study}

Calgary, Canada $\left(52^{\circ} \mathrm{N}\right)$ is selected for this study due to its dense urban-centric infrastructure and being one of the fastest growing Canadian metropolitan area. This study is divided into five main parts as shown in Figure 1 and additionally summarized below.

1. The first part aims at developing a reference or base-case model for a typical supermarket retail block.

2. The second stage aims at developing reference or base-case residential models.

3. The third stage comprises a detailed parametric approach used to determine design criteria for the residential-retail complex to maximize energy efficiency. Retail sector represents both attached and detached models.

4. The fourth part investigates the residential-retail complex to generate on-site electricity by employing BIPV panels.

5. The last part of the study focuses on exploring waste heat recovery and sharing surplus heat between the retail and residential sector to reduce dependence on utility grid.

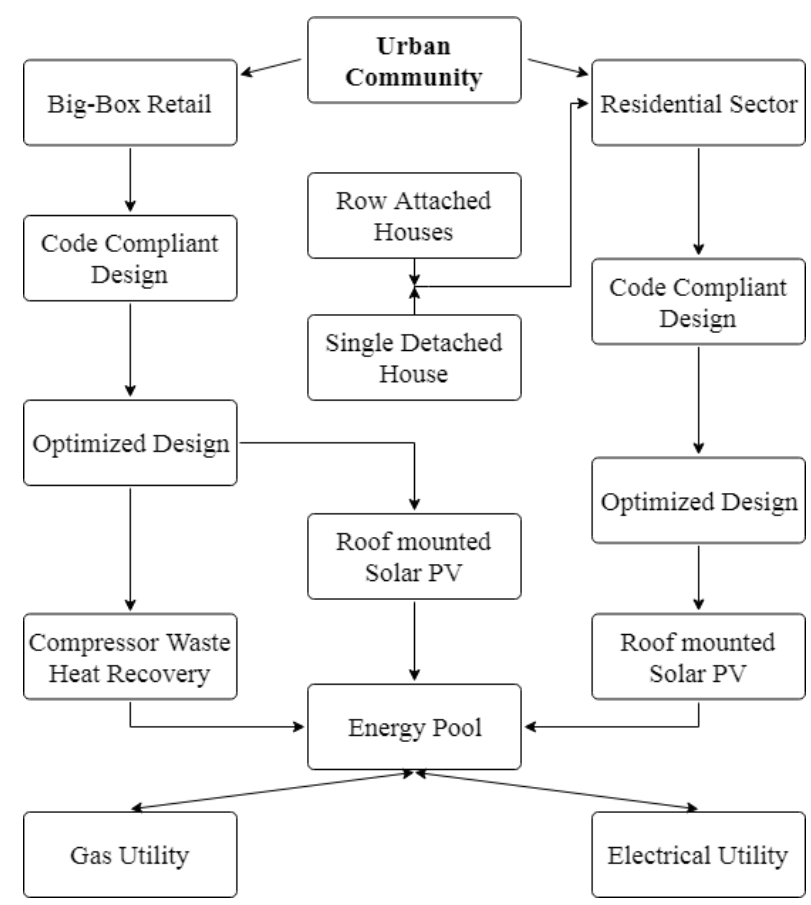

Figure 1 Schematic of Study Methodology

\section{Development of Code Compliant Models}

The baseline model is developed using a number of codes and standards including the Alberta Building Code (2014), ASHRAE Standard 90.1 (2010) and National Energy Code for Buildings (2011). These codes are mandated by law for all buildings at the project site. EnergyPlus is used for the overall simulations and analysis. EnergyPlus is a whole building energy simulation program used to model both energy consumption for heating, cooling, ventilation, lighting and plug and process loads and water use in buildings (EnergyPlus, 2015).

\section{Retail Area}

The supermarket retail assumes a basic geometric rectangular design of $45 \mathrm{~m}$ x $45 \mathrm{~m}$ plan dimensions and $4.3 \mathrm{~m}$ height. Overall window area for the retail has been modelled at $0 \%$ and the lighting has been modelled at 8 $\mathrm{W} / \mathrm{m}^{2}$. Insulation for the retail has been modelled at RSI $3.3 \mathrm{~m}^{2} \mathrm{~K} / \mathrm{W}$ for the exterior walls and $5 \mathrm{~m}^{2} \mathrm{~K} / \mathrm{W}$ for the roof as per the investigation done by Syed and Hachem (2019).

A cold-room of dimensions of $30 \mathrm{~m} \times 10 \mathrm{~m} \times 4.3 \mathrm{~m}$ within the retail area has been modelled. The cold-room houses all medium range temperature displays. In order to reduce merchandizing concerns and for the customers to see the available produce (Boros, 2016), a double glazed clear pane assembly is used as a boundary wall.

The key design parameters are presented in Table 1. Table 1: Retail Design Inputs

\begin{tabular}{|c|c|}
\hline Parameter & Value \\
\hline Insulation RSI & Walls: 3.3, Roof: 5 \\
\hline Area - Retail & $45 \mathrm{~m} \mathrm{x} \mathrm{35} \mathrm{m} \mathrm{x} \mathrm{4.3} \mathrm{m}$ \\
\hline Area - Cold-room & $30 \mathrm{mx} \mathrm{10} \mathrm{m} \mathrm{x} \mathrm{4.3} \mathrm{m}$ \\
\hline Fenestration area - Retail & $0 \%$ \\
\hline
\end{tabular}

\section{Residential Sector}

Based on the Survey of Household Energy Use, Detailed Statistical Report (SHEU, 2011), the most common house types in Canada are single detached followed by row houses. House types, occupants, number of storeys, heating source, type of cooling, temperature set-points, hot water system and types of plumbing fixtures have been modelled as per SHEU (2011). The envelope insulation values and appliance efficiencies and performance coefficients are modelled to meet the minimum requirements of the Alberta Building Code (2014). One single detached house and one row house (comprised of three attached houses) is modelled for this study.

The key design parameters for residential models are presented in Table 2 . 
Table 2: Residential Design Inputs

\begin{tabular}{|c|c|}
\hline Parameter & Value \\
\hline No. of Occupants & 4 \\
\hline Conditioned Area & $233 \mathrm{~m}^{2}$ (Single), $125 \mathrm{~m}^{2}$ (Row) \\
\hline No. of Storeys & 2 \\
\hline Heating System & Natural gas Furnace \\
\hline Cooling System & Central air conditioner \\
\hline Hot Water System & Natural gas \\
\hline Ceiling below attics & 10.43 RSI \\
\hline Roof Insulation & 5.02 RSI \\
\hline Above grade Walls & 3.08 RSI \\
\hline Below grade walls & 3.46 RSI \\
\hline Slab on grade & 3.72 RSI \\
\hline Doors and windows & 1.60 USI \\
\hline Vehicle access doors & 1.1 RSI \\
\hline
\end{tabular}

Figure 2 shows geometry of residential-retail models as modelled for this study.

\section{Design Improvement of Retail-Residential Complex}

Numerous innovative technologies and high-energy efficiency measures (ECM) are modelled in EnergyPlus to improve the energy performance of retail-residential complex (Complex, hereafter). Details are presented below:

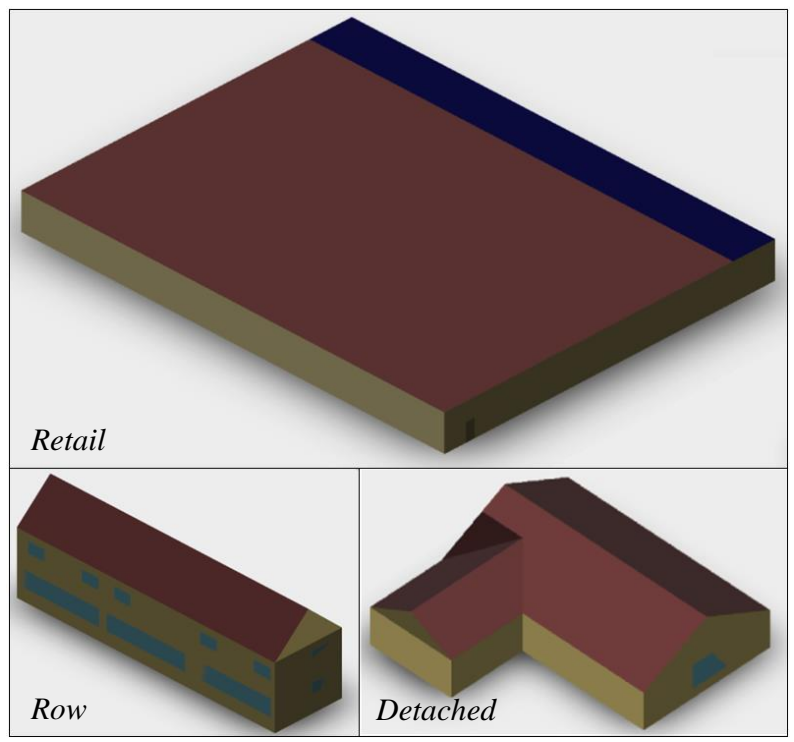

Figure 2 Geometry of Residential-Retail Models

\section{Retail Model}

HVAC Air-side Economizer

The HVAC air-side economizers have been modelled in EnergyPlus. Based on the typical design practice, the compressor lockout temperature set at $20^{\circ} \mathrm{C}$ is used.

\section{Heat Recovery Ventilation}

Heat recovery ventilation employing the heat exchanger has been modelled in EnergyPlus with net heat recovery effectiveness for these wheels is approximately around 0.65 (i.e. $65 \%$ ).
Upgrading Appliance and Plug Loads

Plug loads for the retail area are based on ASHRAE Standard for the Design of High-Performance Green Buildings 189.1 (ASHRAE 189.1, 2014). This amount to the appliance/plug load equivalent to $2.7 \mathrm{~W} / \mathrm{m}^{2}$ for the retail (ASHRAE 189.1, 2014).

\section{Lighting Upgrades}

The lighting controls have been modelled in EnergyPlus at $7.5 \mathrm{~W} / \mathrm{m}^{2}$ as per ASHRAE Standard 90.1 (ASHRAE 90.1, 2010). Exterior site lighting has been modified to run till the mid-night and then switch to turning off every alternate exterior lamp.

\section{Process Refrigeration Compressor Upgrades}

A multi-stage compressor with magnetic bearings has been modelled in EnergyPlus, with the nominal coefficient of performance (COP) of 4.5.

\section{Water Conserving Service Hot Water Faucets}

Low flow faucets with a rating of 1.9 Litre/min flow is modelled in the EnergyPlus based on Canada Green Building Council (CaGBC) templates for the LEED 2009 (CaGBC, 2018).

\section{Hands Free Controls for Service Hot Water Faucets}

Studies have shown that the use of automatic, hands-free faucet controls can reduce the service hot water usage significantly (LEED, 2009). $30 \%$ reduced service hot water load has been assumed for this ECM, following the design guidelines of innovative wastewater technologies per LEED (2009).

\section{Waste Heat Recovery from Compressor Racks}

Waste heat from compressor racks is recovered and shared between the retail and residential models. Energy sharing strategy and results are discussed later in this paper.

\section{Residential (Detached \& Row) Models}

\section{Envelope Upgrade}

Envelope insulation values are increased to meet the requirements of ASHRAE 189.1 (2014). Roof: 7.29 RSI, Wall: 3.81 RSI, Windows 1.65 USI.

\section{Lighting Upgrades}

The lighting controls have been modelled in EnergyPlus at $4.5 \mathrm{~W} / \mathrm{m}^{2}$ as per ASHRAE Standard 189.1 (2014).

\section{Upgrading Appliance and Plug Loads}

Improved appliance/plug load equivalent to $5.0 \mathrm{~W} / \mathrm{m}^{2}$ for residential models is used (ASHRAE 189.1, 2014).

\section{Pipe and Duct Insulation}

Pipe and duct insulations are modelled as per the requirement of ASHRAE 189.1 (2014).

\section{$\mathrm{CO}_{2}$ based Demand Control Ventilation}

Outdoor air reset based demand control ventilation is modelled with $30 \%$ reduction in the ventilation air. 


\section{Air Furnace Upgrades}

Residential air furnaces are upgraded with $95 \%$ efficient heating coils and a cooling COP of 4.5.

\section{HVAC Air-side Economizer}

Based on the typical design practice, the compressor lockout temperature set at $20^{\circ} \mathrm{C}$ is used.

\section{Night Set-back}

Winter night set-back of $21^{\circ} \mathrm{C}$ is modelled for the houses.

\section{Humidifier Upgrades}

Residential humidifier is improved to $98 \%$ efficiency.

\section{Heat Recovery Ventilation}

Heat recovery ventilation with a net heat recovery effectiveness of 0.85 (i.e. $85 \%$ ) is modelled.

\section{Drain Water Heat Recovery}

Drain water heat recovery system is modelled for the residential models in the EnergyPlus.

\section{On-site Photovoltaic Energy Generation}

Solar photovoltaic (PV) system is modelled for the retail and residential models. In the case of the Complex design, it is assumed to have a two-way electric utility meter to import the electricity when the renewable energy systems are not able to meet the demand and export energy to the utility grid when excess generation occurs in the real-time. The PV system for the Complex is modelled in EnergyPlus. Crystalline Silicon PV cells are modelled with system efficiency of $15 \%$ for the retail model. For residential models, an integrated PV system is modelled on the south facing roof surfaces of both the detached and row houses, respectively.

Roof area required for the installation of $1 \mathrm{~kW}$ solar PV system is found to be approximately $10 \mathrm{~m}^{2}$ based on preliminary estimates from SolarRoof (2018), NREL (2004) and Alberta Infrastructure (2018). While it is understood that the solar PV system potential varies on the system performance parameters, site orientation and location, a detailed PV system analysis is outside the scope of the current study.

Based on the gross roof area of the retail, approximately $1,500 \mathrm{~m}^{2}$ of the roof area is available for the PV systems. $75 \%$ of the total roof area is modelled with the PV system to account for rooftop HVAC system. Similarly, for row houses a total of $135 \mathrm{~m}^{2}$ and for detached house a total of $100 \mathrm{~m}^{2}$ of roof area is dedicated to the PV array.

\section{Thermal and Electrical Energy Sharing}

Waste heat recovered from the compressor rack is used for space and ventilation air heating for the residential and retail models. The deficit heat supply is provided by HVAC systems for each building.
Energy sharing between the individual buildings of the Complex can be formulated as shown in Equation 1 . Equation 1 shows that at any given point the amount of energy shared between individual structures of the Complex is equal to the net balance of energy. Hence, at a given point in time, the amount of energy shared between the individual buildings of Complex is equal to the difference between the surplus energy in the Complex boundary and the deficit of energy for the individual buildings in the Complex.

$$
\text { Energy }_{\text {Share }}=\min \left[\sum \text { Energy }_{\text {Surplus }}, \sum \text { Energy }_{\text {Deficit }}\right]
$$

Energy supply from the neighbouring building is available in energy sharing cases as shared amount of electricity $\left(\mathrm{E}_{\text {share }}\right)$ and heat $\left(\mathrm{H}_{\text {share }}\right)$.

The amount of shared energy at each time of day can be calculated according to the net balance in the total $\mathrm{E}_{\text {share }}$ and the total $\mathrm{H}_{\text {share }}$ of all buildings within the Complex. Surplus electricity, which is not utilised completely within the Complex, is exported to the utility grid $\left(E_{\text {export }}\right)$. The excess heat after sharing is released into the air $\left(\mathrm{H}_{\text {exhaust }}\right)$.

Two scenarios of thermal energy sharing (Air-to-Air Heat Recovery and District Energy System) have been modelled to assess the range of potential of energy sharing in the Complex. The schematics of energy sharing pathways explored in this study are presented in Figure 3 below:

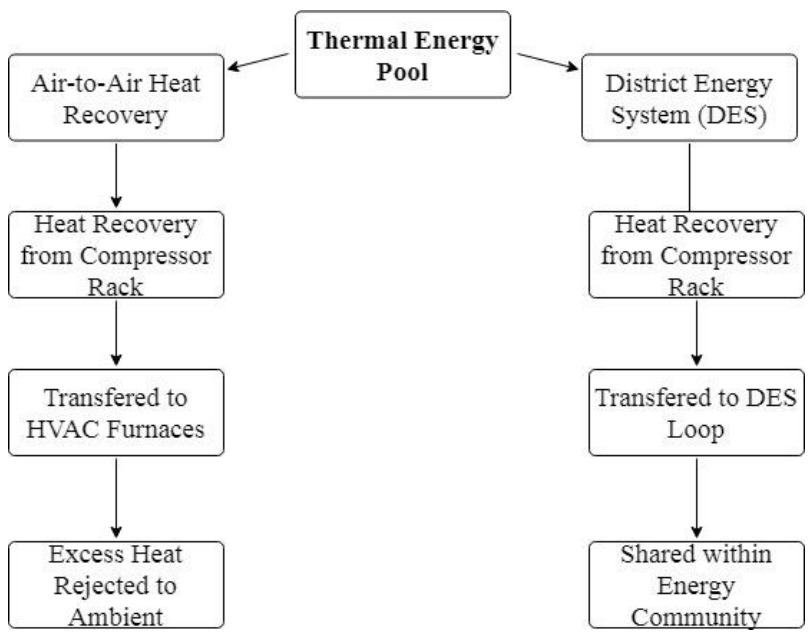

Figure 3 Schematics of Energy Sharing Scenarios

\section{Air-to-Air Heat Recovery}

In this model, it is assumed that the compressor waste heat is recovered by air-to-air heat exchangers and is shared directly with the HVAC air furnaces of the houses. The remainder of the compressor waste heat is shared with the HVAC system serving the retail. Since no heat storage system is modelled for this study, any excessive heat not used by the Complex is exhausted to the outdoor environment.

There are several types and applications of air-to-air heat exchangers, with varying levels of heat recovery 
effectiveness (ASHRAE, 2016). ASHRAE (2016) summarizes the following primary types of air-to-air heat exchangers:

- Fixed-Plate Heat Exchangers

- Rotary Air-to-Air Energy Exchangers

- Coil Energy Recovery (Runaround) Loops

- Desiccant and Heat Wheel Systems

- Heat Pipe Heat Exchangers

- Thermosiphon Heat Exchangers

Comparison of different types of energy recovery systems is based on certified ratings such as sensible, latent and total effectiveness, air-leakage rates, capital cost, service life, maintenance cost and their suitability for a particular application (ASHRAE, 2016). Based on ASHRAE (2016), counter flow, fixed plate heat exchanger is the most suitable option for the current study due to the following attributes of the fixed plate heat exchangers:

- Equipment size is smaller

- Typical sensible effectiveness $=75 \%$

- Face velocity of $1 \mathrm{~m} / \mathrm{s}$

- Low pressure drop

- Low maintenance and no moving parts

Hence, a fixed plate air-to-air heat recovery system is assumed for this scenario. The compressor rack waste heat is recovered at the effectiveness rate of $75 \%$ and is transferred to the heating coils of HVAC systems for the row house, detached house and retail, respectively.

\section{District Energy System (DES)}

In this scenario a district energy system is assumed which is a central energy conversion and distribution system that provides thermal energy to a boundary that extends beyond the Complex. A DES transports thermal energy as a part of city-wide system, a campus network or just a few neighbouring buildings (CaGBC, 2012). The estimation of the energy efficiency of a DES is determined through monitoring or analytical analysis of heating plants and their thermal distribution losses. However, CaGBC (2012) prescribes default values of a DES system as follows:

- DES heating plant efficiency $=70 \%$

- Thermal distribution losses for hot water $=10 \%$

Therefore, the net DES performance is efficiency (\%) $\mathrm{x}$ [100\% - distribution loss (\%)] (CaGBC, 2012). This amounts to a default DES efficiency of $63 \%$.

Hence, a DES is assumed with effectiveness $63 \%$ and compressor rack waste heat is transferred to the DES loop and is thus shared with heating coils of HVAC systems for the row house, detached house and retail, respectively.

\section{Results and Discussion}

This section presents the simulation results and discussion on this study.

\section{Code Compliant Scenario}

Table 3 presents the results of code compliant base models. The code compliant model for Retail has annual energy of $2980 \mathrm{GJ} / \mathrm{Yr}$ with an energy density of 1.29 $\mathrm{GJ} / \mathrm{m}^{2}$. Row House model has the annual energy of 287 $\mathrm{GJ} / \mathrm{Yr}$ with an energy density of $0.75 \mathrm{GJ} / \mathrm{m}^{2}$. Detached House model has the annual energy of $287 \mathrm{GJ} / \mathrm{Yr}$ with an energy density of $0.75 \mathrm{GJ} / \mathrm{m}^{2}$.

\section{Energy Efficient Complex Model}

Table 4 shows energy performance with the energy efficiency strategies modelled for the Complex. Retail shows a reduction of $29 \%$ in annual energy use, Row House $32 \%$ and Detached House shows a $41 \%$ reduction in the annual energy use compared to the code compliant baseline designs. Figure 4 and Figure 5 show the energy saving percentages per ECM compared to the reference baseline model for retail and residential models, respectively. Figure 6 shows an overall comparison between the code compliant baseline model and the cumulative effect of energy efficiency measures for retail, row and detached house models, respectively.

\section{On-site Renewable Energy}

On-site electricity is generated by solar PV cells. Table 5 shows the renewable electricity produced and percentage of electrical load satisfied on a yearly basis by each building in the Complex.

Excess energy generated by the PV system is exported to the utility grid. Similarly, when there is a net deficit the electrical energy is imported from the utility grid. Figure 7 shows the flow of net electrical energy in the Complex. Between the months of March to August, there is a net export to the utility. Similarly, between the months of September to February, there is a net import from the utility.

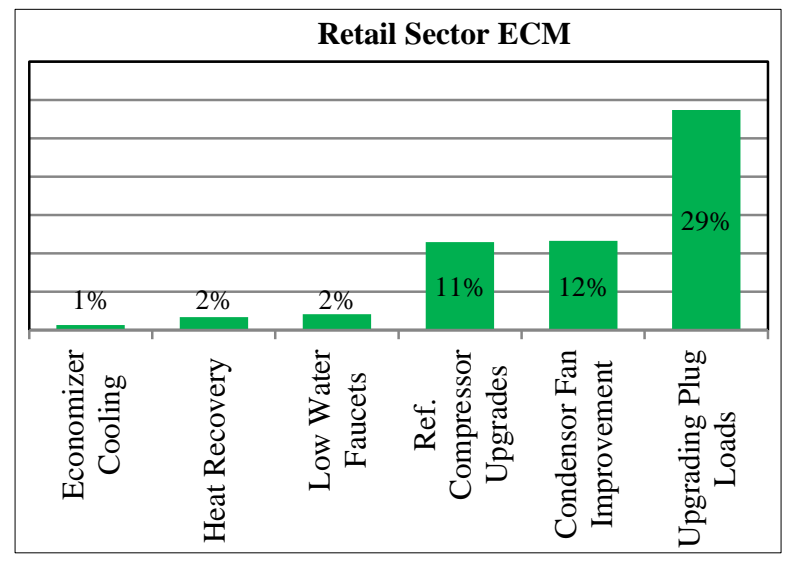

Figure 4 Energy Conservation Measures for Retail 
Table 3: Annual Energy Use of Complex

\begin{tabular}{|c|c|c|}
\hline \multirow[b]{2}{*}{ Retail } & Annual Energy & Energy Density \\
\hline & $\begin{array}{l}2980 \mathrm{GJ} / \mathrm{Yr} \\
(825 \mathrm{MWh})\end{array}$ & $\begin{array}{c}1.29 \mathrm{GJ} / \mathrm{m}^{2} \\
\left(358 \mathrm{kWh} / \mathrm{m}^{2}\right)\end{array}$ \\
\hline End Uses & \multicolumn{2}{|c|}{ Percentage } \\
\hline Heating & \multicolumn{2}{|c|}{55} \\
\hline Cooling & \multicolumn{2}{|c|}{1} \\
\hline Interior Lighting & \multicolumn{2}{|c|}{6} \\
\hline Miscellaneous & \multicolumn{2}{|c|}{4} \\
\hline Refrigeration & \multicolumn{2}{|c|}{34} \\
\hline \multirow[b]{2}{*}{ Row House } & Annual Energy & Energy Density \\
\hline & $\begin{array}{l}287 \mathrm{GJ} / \mathrm{Yr} \\
(79 \mathrm{MWh})\end{array}$ & $\begin{array}{c}0.75 \mathrm{GJ} / \mathrm{m}^{2} \\
\left(208 \mathrm{kWh} / \mathrm{m}^{2}\right)\end{array}$ \\
\hline End Uses & \multicolumn{2}{|c|}{ Percentage } \\
\hline Interior Lighting & \multicolumn{2}{|c|}{8} \\
\hline Space Heating & \multicolumn{2}{|c|}{65} \\
\hline Space Cooling & \multicolumn{2}{|c|}{5} \\
\hline Fans & \multicolumn{2}{|c|}{2.5} \\
\hline Water Heating & \multicolumn{2}{|c|}{13} \\
\hline Miscellaneous/Plug & \multicolumn{2}{|c|}{6.5} \\
\hline \multirow[b]{2}{*}{ Detached House } & Annual Energy & Energy Density \\
\hline & $\begin{array}{c}447 \mathrm{GJ} / \mathrm{Yr} \\
(124 \mathrm{MWh})\end{array}$ & $\begin{array}{c}0.9 \mathrm{GJ} / \mathrm{m}^{2} \\
\left(250 \mathrm{kWh} / \mathrm{m}^{2}\right)\end{array}$ \\
\hline End Uses & \multicolumn{2}{|c|}{ Percentage } \\
\hline Interior Lighting & \multicolumn{2}{|c|}{6.5} \\
\hline Space Heating & \multicolumn{2}{|c|}{57} \\
\hline Space Cooling & \multicolumn{2}{|c|}{3.5} \\
\hline Fans & \multicolumn{2}{|c|}{5} \\
\hline Water Heating & \multicolumn{2}{|c|}{13.5} \\
\hline Receptacle Load & \multicolumn{2}{|c|}{11.5} \\
\hline Miscellaneous & \multicolumn{2}{|c|}{3} \\
\hline
\end{tabular}

Table 4: Results with ECM

\begin{tabular}{|c|c|c|}
\hline Building & Energy Use/Year & Energy Saved \\
\hline Retail & $\begin{array}{c}2,100 \mathrm{GJ} \\
(581 \mathrm{MWh})\end{array}$ & $29 \%$ \\
\hline Row House & $\begin{array}{c}197 \mathrm{GJ} \\
(54 \mathrm{MWh})\end{array}$ & $32 \%$ \\
\hline Detached House & $\begin{array}{c}262 \mathrm{GJ} \\
(72 \mathrm{MWh})\end{array}$ & $41 \%$ \\
\hline
\end{tabular}

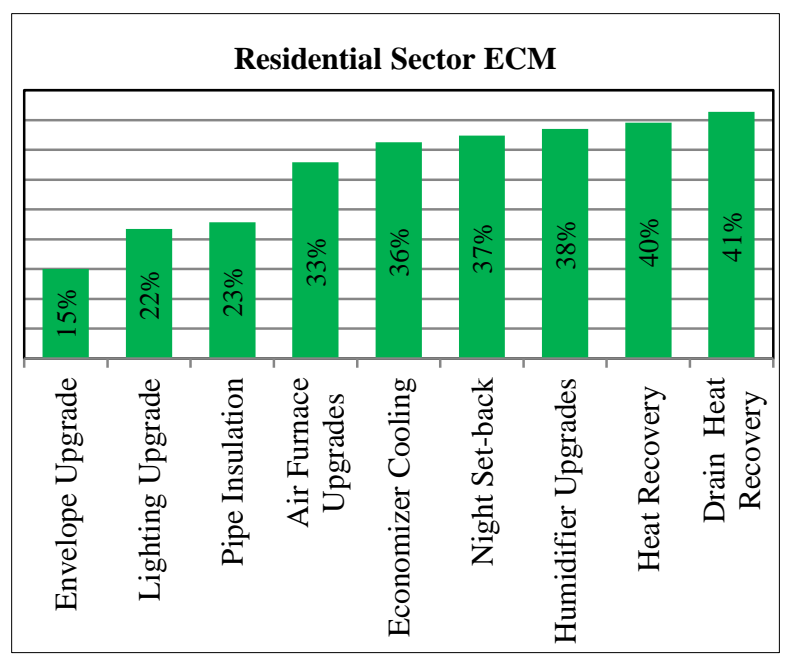

Figure 5 Energy Conservation Measures for Detached House

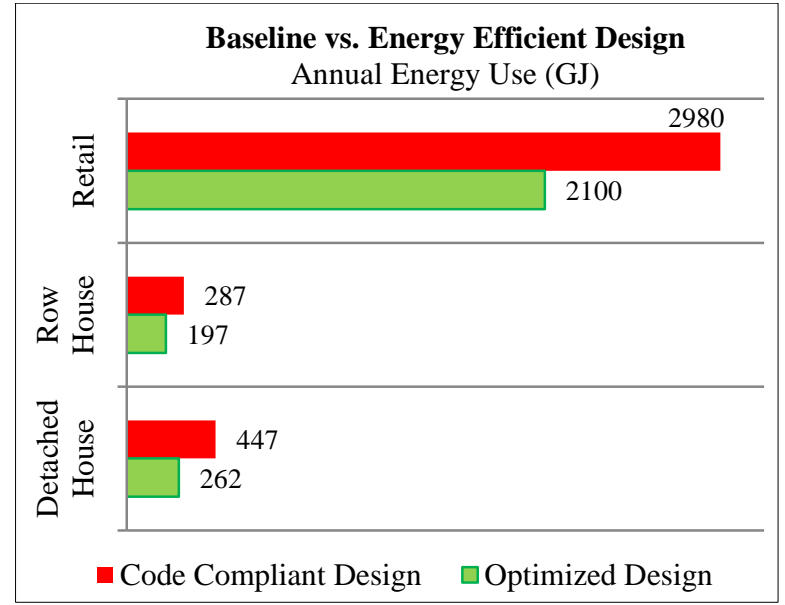

Figure 6 Baseline vs. Energy Efficient Design

Table 5: On-site Electricity Generated

\begin{tabular}{|c|c|c|}
\hline Building & Energy/Year & $\begin{array}{c}\text { \% of Yearly } \\
\text { Electricity }\end{array}$ \\
\hline Retail & $\begin{array}{c}817 \mathrm{GJ} \\
(226 \mathrm{MWh})\end{array}$ & $86 \%$ \\
\hline Row House & $\begin{array}{c}61 \mathrm{GJ} \\
(17 \mathrm{MWh})\end{array}$ & $100 \%$ \\
\hline Detached House & $\begin{array}{c}63 \mathrm{GJ} \\
(17 \mathrm{MWh})\end{array}$ & $96 \%$ \\
\hline
\end{tabular}

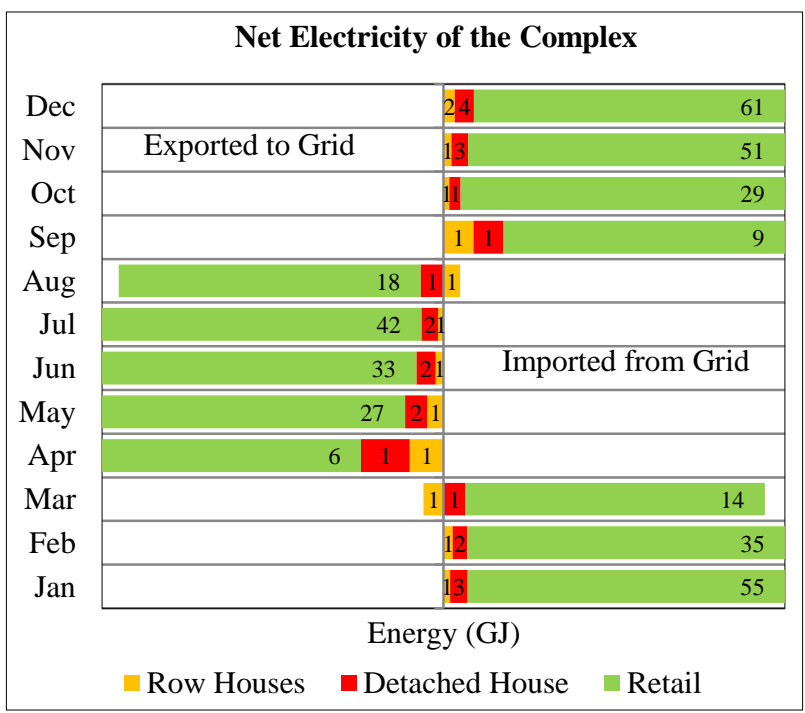

Figure 7 Net Electricity of the Complex

Compressor Rack Waste Heat Recovery and Thermal Energy Sharing

Heat rejection is the excess heat from a cooling system which is removed by the retail area refrigeration units. Heat rejection is the total amount of heat energy which is transferred from the cool side to the warm side, plus the work carried out by the refrigeration compressor. Gross refrigeration energy transfer from the retail in the energy pool is approximately 1226 GJ per year. By sharing waste heat recovered from retail refrigeration compressor racks, up to $68 \%$ of the space and ventilation heating demand of the retail-residential 
complex can be met using Air-to-Air Heat Exchangers, with approximately 5 GJ of energy exhausted to the outdoors. With a DES system, approximately $58 \%$ of of the space and ventilation heating demand of the retailresidential complex can be met with no heat exhausted to the outdoors. The results of both thermal energy sharing scenarios (air-to-air heat transfer and DES) are presented in Table 6 below:

\begin{tabular}{|c|c|}
\multicolumn{1}{|c}{ Table 6: Thermal Energy Sharing Results } \\
\hline Energy in Pool & $\begin{array}{c}\mathbf{1 2 2 6} \text { GJ } \\
\mathbf{3 4 0} \text { MWh })\end{array}$ \\
\hline Scenarios - Air-to-Air Heat Exchanger \\
\hline Total Complex Heating Energy & $\begin{array}{c}1330 \mathrm{GJ} / \mathrm{Yr} \\
(368 \mathrm{MWh})\end{array}$ \\
\hline Thermal Energy Recovered from Pool & $\begin{array}{c}919 \mathrm{GJ} / \mathrm{Yr} \\
(254 \mathrm{MWh})\end{array}$ \\
\hline Complex Heating Energy Reduction & $69 \%$ \\
\hline Energy Exhausted to Ambient & $\begin{array}{c}5 \mathrm{GJ} / \mathrm{Yr} \\
(1.4 \mathrm{MWh})\end{array}$ \\
\hline Scenarios - District Energy System \\
\hline Total Complex Heating Energy & $\begin{array}{c}1330 \mathrm{GJ} / \mathrm{Yr} \\
(368 \mathrm{MWh})\end{array}$ \\
\hline Thermal Energy Recovered from Pool & $\begin{array}{c}772 \mathrm{GJ} / \mathrm{Yr} \\
(214 \mathrm{MWh})\end{array}$ \\
\hline Complex Heating Energy Reduction & $58 \%$ \\
\hline Energy Exhausted to Ambient & $\begin{array}{c}0 \mathrm{GJ} / \mathrm{Yr} \\
(0 \mathrm{MWh})\end{array}$ \\
\hline
\end{tabular}

\section{Conclusion}

This study shows that with the energy efficient design using cutting edge technologies and high energy efficiency measures in the architectural, mechanical, electrical and plumbing design of the Complex, the energy density has been reduced by $29 \%$ for Retail, 32 $\%$ for Row house and $41 \%$ for Detached house, respectively. Similarly, adding on-site PV system meets $86 \%$ of electrical energy demand for Retail, $100 \%$ for Row house and $96 \%$ for Detached house, respectively on a yearly basis.

Waste heat recovered from the refrigeration compressor racks is employed to heat the Retail, Row and Detached houses. Total refrigeration heat rejection amounts to approximately $1126 \mathrm{GJ} / \mathrm{Yr}$. Based on the heat recovery system, the total heating demand of the Complex can reduced by $69 \%$ per year using air-to-air heat recovery and $58 \%$ per year for a district energy system on an hourly basis. The comparison of energy flow from utility has shown that energy sharing within the Complex can result in significant energy usage reduction compared to treating buildings as separate.

This paper addresses the gap in existing research concerning design options of retail and residential sector and demonstrates innovative approach to achieve highenergy performance. The results of the study provide useful information when making decisions for the architectural and engineering design processes of an urban centric retail amenity and residential sector. With the proposed design approach, this study provides a basis of an effective energy feasibility design of urban centric infrastructure.

\section{Acknowledgement}

The authors want to thank NSERC Discovery Grant for the financial support.

\section{References}

AEDG (2011). Advanced Energy Design Guide for Bix Box Retail Buildings, American Society for Heating, Ventialtion and Air-Conditioning.

Alberta Building Code (2014). National Research Council, Government of Canada.

ASHRAE (2014). American Society for Heating Ventilation \& Air-Conditioning Handbook, HVAC Refrigeration, IP Edition.

ASHRAE (2016). American Society for Heating Ventilation \& Air-Conditioning Handbook, HVAC Systems and Equipment, SI Edition.

ASHRAE 90.1 (2010). American Society for Heating Ventilation \& Air-Conditioning, Energy Standard for Buildings Except Low-Rise Residential Building, IP Edition.

ASHRAE Standard 90.1 User's Manual (2016). Standard 90.1 User's Manual, American Society for Heating Ventilation \& Air-Conditioning, Energy Standard for Buildings Except Low-Rise Residential Building.

ASHRAE 189.1 (2014). American Society for Heating Ventilation \& Air-Conditioning, Standard for the Design of High-Performance Green Buildings.

ASHRAE 62.1 (2016). American Society for Heating Ventilation \& Air-Conditioning, Ventilation for Acceptable Indoor Air Quality.

Benis Khadija, Reinhart Christoph, Ferrao Paulo (2017). Development of a simulation-based decision support workflow for the implementation of BuildingIntegrated Agriculture (BIA) in urban contexts, Journal of Cleaner Productions 147 (2017) 589602.

Boros Péter, Fehér Orsolya, Lakner Zoltán, Niroomand Sadegh, Vizvári Béla, Modeling supermarket relayout from the owner's perspective, Annals of Operations Research, 2016, Volume 238, Number 12, Page 27.

CaGBC (2012). Canada Green Buildings Council, LEED Canada 2009 Interpretation Guide for District Energy Systems.

CaGBC (2018). Canada Green Buildings Council, https://www.cagbc.org/CAGBC/Programs/LEED/U pdated_CS and NC 2009 Letter_Templates.aspx Accessed: March 2018.

Chung Mo, Park Chuhwan, Lee Sukgyn, Park HwaChoon, Im Yong-Hoon, Chang Youngho (2012). A decision support assessment of cogeneration plant for a community energy system in Korea, Energy Policy 47 (2012) 365-383. 
Doty, Steve (2008). Commercial Energy Auditing Reference Handbook, 53-57.

EnergyPlus (2015). Engineering Reference, Version 8.4.0 Documentation, U.S. Department of Energy.

Kayo Genku, Hassan Ala, Siren Kai (2014). Energy sharing and matching in different combinations of buildings, CHP capacities and operation strategy, Energy and Buildings 82 (2014) 685-695.

Kayo Genku, Ooka Ryozo (2010a), Building energy system optimizations with utilization of waste heat from cogenerations by means of genetic algorithm, Energy and Buildings 42 (2010) 985-991.

Kayo Genku, Ooka Ryozo (2010b), Potential to reduce energy consumption by establishing distributed energy system in the exiting office and apartment buildings, Adapting to Change: New Thinking on Comfort, Cumberland Lodge, Windsor, UK, 9-11 April 2010. London: Network for Comfort, and Energy Use in Buildings.

Kayo Genku, Ooka Ryozo (2010), Potential to reduce energy consumption by establishing distributed energy system in the exiting office and apartment buildings, Proceedings of Conference: Adapting to Change: New Thinking on Comfort Cumberland Lodge, Windsor, UK, 9-11 April 2010. London: Network for Comfort and Energy Use in Buildings, http://nceub.org.uk

Hachem-Vermette Caroline, Guarino Francesco, La Rocca Vincenzo, CelluraMaurizio (2018). Towards achieving net-zero energy communities: Investigation of design strategies and seasonal solar collection and storage net-zero. Solar Energy.

LEED (2009). LEED ${ }^{\circledR}$ Canada Green Building Council, Reference Guide for Green Building Design and Constraiuciton.

Nall, Daniel (2017), Integration of Refrigeration and HVAC in grovery stores, ASHRAE Journal, 59 (1)

National Energy Board (2018). Canada's Energy Future 2018, An Energy Market Assessment, Government of Canada.

National Energy Code of Canada for Buildings (2011). National Research Council, Government of Canada.

NREL (2004). How much land will PV need to supply our electrIcIty, National Renewabkle Energy Laboratory, DOE/GO-0102004-1835

Seto, K.C., Dhakal, S., Bigio, A., Blanco, H., Delgado, G.C., Dewar, D., Huang, L., Inaba, A., Kansal, A., Lwasa, S. and McMahon, J., 2014. Human settlements, infrastructure and spatial planning.

SHEU (2011). Survery of Household Energy Use, Detailed Statistical Report, Office of Energy Efficiency, Natural Resources Canada.

SolarRoof (2018). Solar Roof Calcualtor, http://www.solarroofcalculator.appspot.com/

Syed, Ali, Hachem-Vermette, Caroline, (2019). Climate Change Resilient Urban Prototypes-A Canadian
Perspective on Net Zero Energy Design for Retail Amenities, Energy Engineering, 116:1, 725, DOI: 10.1080/01998595.2019.12043335.

UN-Habitat (2011). Cities and Climate Change: Global Report in Human Settlements. 2011.

UN-Habitat (2012). Going Green: A Handbook of Sustainable Housing Practices in Developing Countries.

UN-Habitat (2014), Planning for Climate Change. 